\title{
Identification of Areas for Sustainable Settlements in Highly Conflicted Protected Areas Using ArcGIS Spatial Analyst: A Case of Chobe District, Botswana
}

\author{
Issa Kaduyu ${ }^{1}$, Godiraone Yuyi ${ }^{1} \&$ Ednah Kgosiesele ${ }^{1}$ \\ ${ }^{1}$ Department of Agricultural and Biosystems Engineering, the Botswana University of Agriculture and Natural \\ Resources, Gaborone, Botswana \\ Correspondence: Issa Kaduyu, Department of Agricultural and Biosystems Engineering, the Botswana University \\ of Agriculture and Natural Resources, Private bag 0027, Gaborone, Botswana. E-mail: kaduyuissa@gmail.com
}

Received: August 24, 2021

doi:10.5539/jsd.v14n5p84
Accepted: September 13, $2021 \quad$ Online Published: September 15, 2021

URL: https://doi.org/10.5539/jsd.v14n5p84

\begin{abstract}
The increasing human settlements around protected areas is a significant cause of the shrinking size of conservation areas globally. This is an alarming situation, especially in countries where protected areas significantly contribute to the National economy. The use of new tools to solve Land use conflicts that exist around protected areas is needed. This study employed the weighted overlay analysis using ecological, social and economic factors to model suitability for developing settlements in Chobe District, an international tourist destination in Northern Botswana, using ArcGIS spatial analyst. The majority of the land (83.4\%) in Chobe is not suitable for settlement, while suitable areas that could for settlement remain relatively small $(0.3 \%$ of the land). This study suggests that more land for settling the increasing population be created out of Chobe District to avoid encroachment on the conservation areas. The study demonstrated that ArcGIS spatial analyst model builder could be integrated into the land resource planning process of protected areas, making it a handy tool for the analysis and the identification of ecological, economic and social factors, thus establishing an excellent area for further research, especially for sustainable management of protected areas.
\end{abstract}

Keywords: protected areas, ArcGis spatial analysis, land conflicts, land suitability, settlements

\section{Introduction}

The consensus between the increasing population in protected areas and the need for conservation remains a challenge for policymakers and practitioners. In recent decades, there has been a rise in reports of encroachment on protected areas globally fuelled by increasing human pressure (Geldmann, Manica, Burgess, Coad, \& Balmford, 2019; Mannetti, 2017; Murti, 2019; UNEP-WCMC, IUCN \& NGS, 2019; Watson, Becker, Milanzi, \& Nyirenda, 2015). Although these areas are critical species conservation areas, some of the ecosystem services and benefits derived from these areas, primarily through tourism, have attracted people to seek residence in these areas. The increase in human pressure in such protected areas, especially in Sub-Saharan Africa, has caused several changes in the ecosystem, including changing flow regime, habitat fragmentation, increased competition for habitats due to expansion of livestock and uncontrolled hunting practices (J. Mbaiwa, 2011; J. E. Mbaiwa \& Stronza, 2010; Moswete, Thapa, \& Child, 2012). The effect of these changes is evident in some protected areas; for instance, in the Maasai Mara, Kenya, the numbers of impala (Aepyceros melampus), warthog (Phacochoerus aethiopicus), giraffe (Giraffa camelopardalis) and hartebeest (Alcelaphus bucelaphus) have been reported to have declined by more than $70 \%$ over the last few decades (Pinnock, 2011).

Over time, people living around and within protected areas tend to derive economic costs and benefits from the areas creating a significant impact on their livelihoods and everyday social relations such as; who within a family lives where, how and why intra-household exchanges occur, and what forms of control individuals have over their own lives (Gupta, 2015). Such complex social, economic and ecological interactions have resulted in conflicts in cases of conflicting interests (Campbell, 1996; von der Dunk, Grêt-Regamey, Dalang, \& Hersperger, 2011). Though often not clearly understood, the complexity of such interrelationships is critical when dealing with landuse conflicts. It seems like conflict is an inevitable part of regional planning processes, especially when the planning involves meeting several incompatible community demands and, if handled constructively, could 
function as an engine for community development.

Several other protected areas are facing the impact of human-wildlife conflict in Africa (Stone, 2013). As governments continue to debate the dangers and merits of biodiversity conservation for human communities, attention must be paid to these changes in the fabric of everyday life for those who live near, and in some cases far, from protected areas. The level of complexity of the environmental, social, economic factors and the number of stakeholders involved in a given system influence the feasibility of solving land-use conflicts (Rodríguez, 2017). West, Igoe, \& Brockington. (2006) reiterate that cases of practitioners disregarding and being ignorant of the social dynamics of areas prioritised for conservation have increased land use conflict and injustices. Therefore, concentration should be on how protected areas have affected spatial distribution in demographics instead of the impact caused by the conflicts since competition for land among various land uses increases, the frequency of land-use conflicts (Ma et al., 2020).

According to Alexander, Ramotadima, \& Sanderson (2018), the demand for land access around resource-rich areas is growing, influencing wildlife conservation and community livelihoods. The projected increase in population may further aggravate the situation and increase demand for land and land resources due to the varying needs of the new population. Therefore, when planning settlement of populations in protected areas, there is a need to understand under what circumstances and what spatial patterns protected areas might influence the settlement of people (Igoe, Brockington, Randall, \& Scholfield, 2008). Areas with the urban-rural interface are expected to experience higher conflict occurrences since these areas are exposed and particularly vulnerable to the influx of population and economic activity and infrastructural development (Halseth, Reimer, Manson, \& Markey, 2009; Nabielek, Kronberger-Nabielek, \& Hamers, 2013). The change in the social structure that arises while creating new settlement areas may lead to land use conflicts, hardship, and social injustices that likely hinder human livelihood and development.

However, creating more land for settlement should sustain economic activities that contribute to the national economy. The integration of different tools in solving such conflicts is critical to achieving sustainable management of conservation areas. This study, therefore, aimed at using an integrated spatial analysis to identify new settlement areas around a protected area to reduce the increasing land-use conflicts in Chobe District, Botswana. The study intended to integrate the interests of different relevant sectors using a sustainable environment point of view (Izakovičová, Miklós, \& Miklósová, 2018). Noteworthy, the potential to diversify the activities within the Chobe district lies in the effectiveness of land allocation for settlement. The need for effective land allocation requires a systematic allocation of land to cater for the increased population. The objectives of this study were; to determine the contribution of different factors to conflict-free and sustainable land use and to identify suitable areas for conflict-free settlements within the Chobe district using ArcGis spatial analyst.

\section{Materials and Methods}

\subsection{Description of the Study Area}

\subsubsection{Location of the Study Area}

The Chobe District of north-western Botswana (Figure 1) is semi-arid dryland supporting a diverse collection of wildlife species and habitats of ecumenical conservation significance, known for its largest elephant population in Africa (Junker, 2008; Stokke \& Toit, 2014). The region receives an annual rainfall of about 550mm. It means monthly temperatures range between $17^{\circ} \mathrm{c}$ and $29^{\circ} \mathrm{c}$ and is characterised by highly variable rainfall, with nearly the entire annual rainfall budget concentrated during the November-March wet season, followed by a general absence of precipitation from April-October. The favourable climate of the area supports a wide variety of land uses, including agriculture, settlements, tourism. Chobe district is the only area in Botswana that can support rainfed agriculture despite limitations due to wildlife conflicts. The Chobe District also has a permanent surface water supply from the Chobe River and its surrounding wetlands. The area is part of a transboundary watershed, the Chobe River Basin, considered a core component of the Kavango-Zambezi (KAZA) Trans-frontier Conservation Area, shared by Angola Botswana, Namibia, Zambia, and Zimbabwe. 


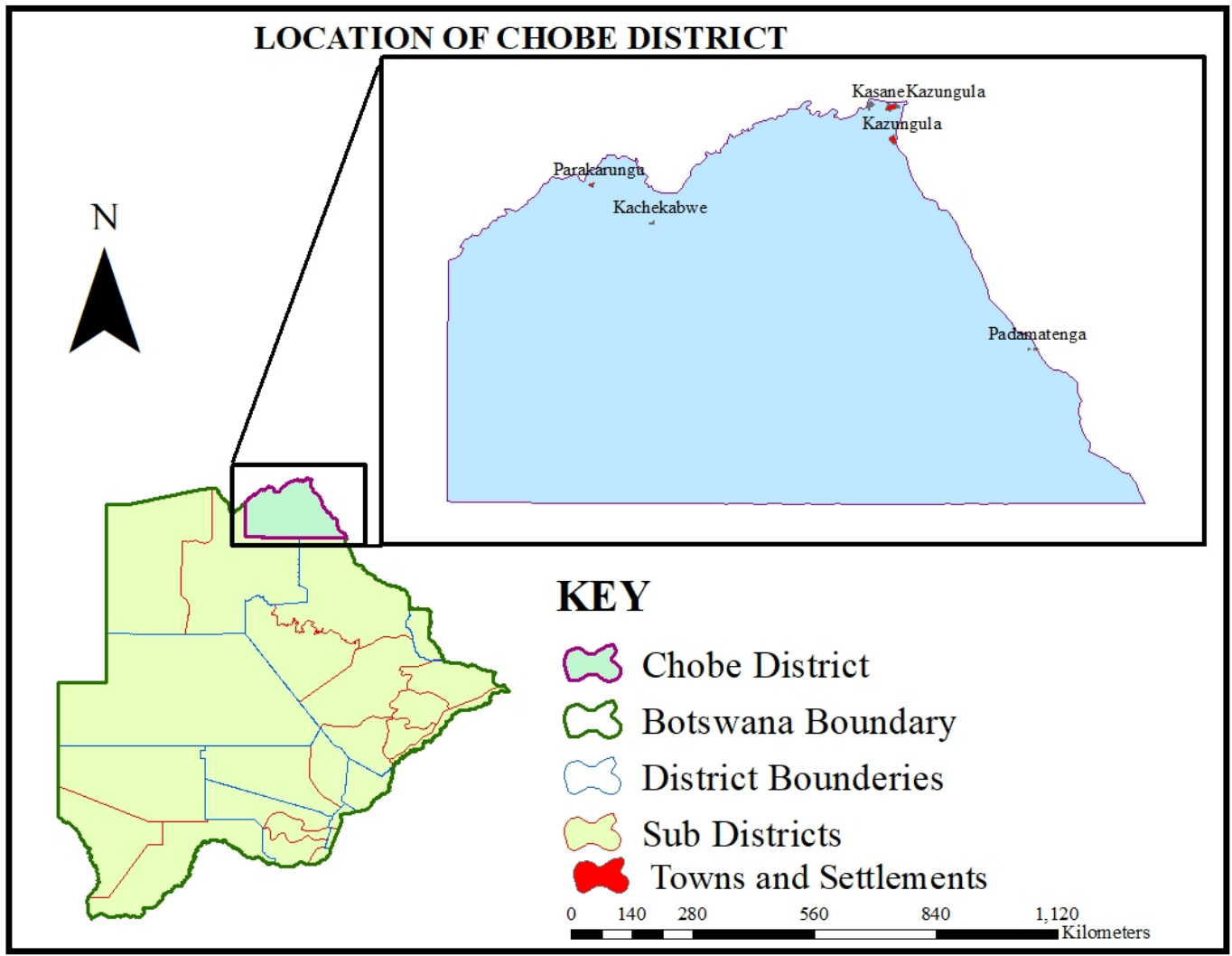

Figure 1. Location of Chobe District

\subsubsection{Land Use and Land-Use Conflicts}

The Chobe District has become an internationally renowned area due to its large wildlife that attracts many tourists throughout the year. Tourism in Botswana has contributed over $13.1 \%$ to the national GDP and $8.9 \%$ to total employment. Although Chobe District is one of the smallest districts in the country, it is endowed with its natural resources, including the Chobe River, forests, and several wildlife species. Over $80 \%$ of the district is for conservation, and only $20 \%$ is devoted to human settlement, industrial development and social amenities (Figure 3). Several factors have influenced population growth in the areas, including the availability of productive soils, rains, government policies, and the increasing tourism potential. Chobe district population increased in previous decades and may reach 32,154 people by 2026 (Figure 2). The majority of this population (39\%) lives in Kasane town (Gupta, 2015). Many people are moving into the district to take advantage of the tourism potential and jobs created by the hotels and camping sites within the area. The exponential increase in population over the years has led to an increase in human pressure on the available natural resources in the district, creating the need to intensify conservation and protection of these natural resources and the environment from being degraded and negatively impacted by the increasing human population and settlement (Gupta, 2015). Besides, according to (Gwebu, 2004), local migration is a common practice among the country's population used as an adaptive strategy to the harsh conditions; this could exacerbate the situation.

The majority of Chobe District is part of the conservation area predominantly inhabited by free-range wildlife. Human settlements in the district have been negatively affected by growth and human livelihood because of the conflicts with wildlife (Fox, 2016; Gupta, 2015; Nijhawan, 2008; van der Sluis et al., 2017). There are several land-use conflicts in the area, with the central conflict being the human-wildlife conflicts. The rise in conflicts is due to the increasing encroachment on conservation land by the increasing population, shrinking carnivore and herbivore habitats and feeding zones. Although the area has potential for crop and livestock production, agricultural production is limited in most areas (van der Sluis et al., 2017). Cases of crop destruction and livestock predation have been reported, mainly from villages living around the Game reserve. Additionally, the local population living within the area predominantly depends on subsistence livestock, crop production and gathering, the creation of restrictions to safari hunting within the Game reserve, which has created more land-use conflicts (J. E. Mbaiwa, 2018). Although hunting greatly influences wildlife numbers, dealing with a change in the 
community's way of life is seemingly a complex process.

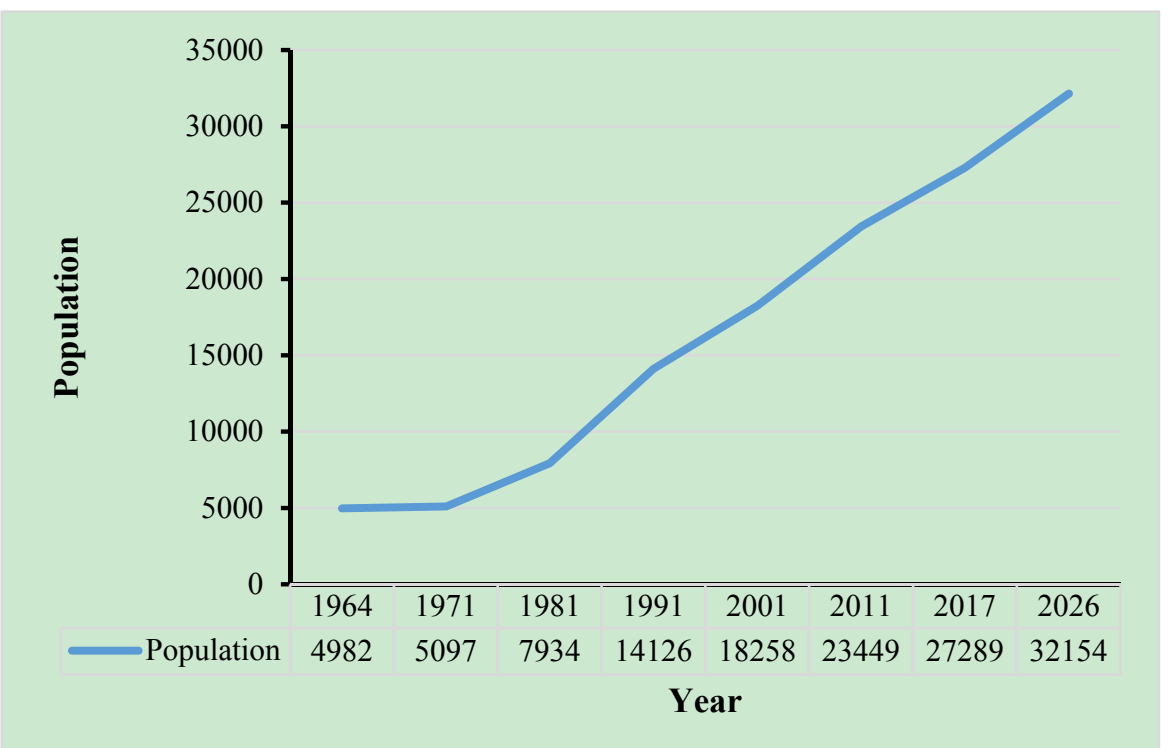

Figure 2. Chobe District population 1964-2017 and projection for 2026 (Statistics Botswana, 2015)

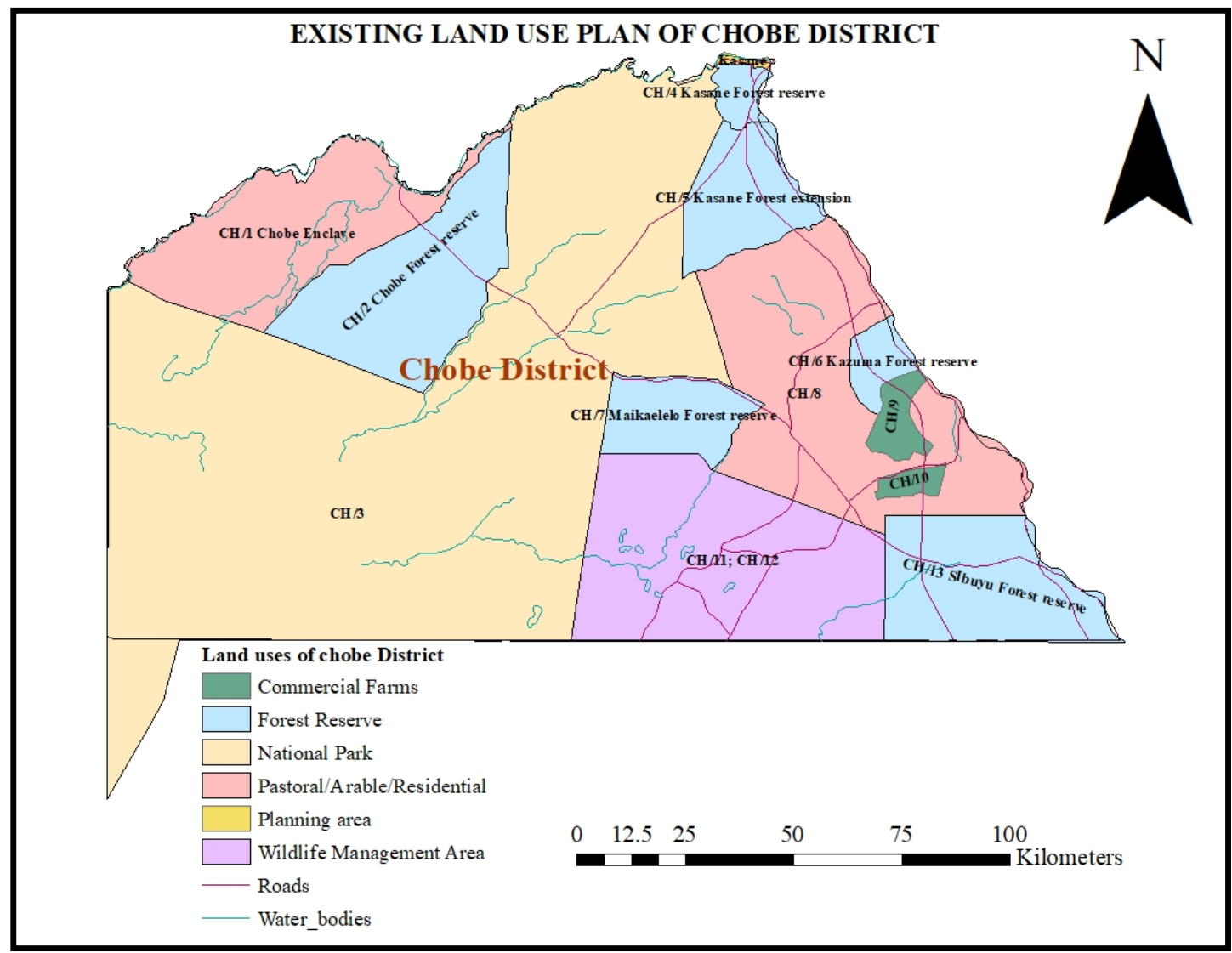

Figure 3. Chobe District current land use plan

A complex human-wildlife interaction characterises Chobe District, and the negative perceptions of the native people could have fuelled an increase in poaching, habitat destruction encroaching into the conservation area, which has negative impacts (Graham, Beckerman, \& Thirgood, 2005; Romañach, Lindsey, \& Woodroffe, 2011). According to Jackson, Mosojane, Ferreira, \& van Aarde. (2008); Madden, (2004) and Nyhus, 2016), human- 
wildlife interactions lead to negative impacts on life and property, economic activities, health, food, and safety when viewed from the human perspective concerning human livelihoods and property. Jackson et al. (2008), Rodríguez (2017), in their studies, also found that the interaction of humans and wildlife and the level of conflict in Chobe District varied according to the spatiotemporal distribution of the species as well as the spatial and temporal scales (seasons). Human-wildlife conflict is often negatively viewed for human life without considering the impact on wildlife (N. Peterson, Birckhead, Leong, M. Peterson, \& T. Peterson, 2010; Soulsbury \& White, 2015). However, such interaction can be managed through several copying strategies to ensure the coexistence of both humans and wildlife for environmental protection, social equity and sustainable development (Adams, 2006; Digun-Aweto \& Van Der Merwe, 2020).

The creation of Safari, hotels, camping sites and other tourism-related services, primarily in the Chobe Enclave area (CH1), has also sparked several conflicts hindering livelihoods within the area (Kemmonye, 2009). There are increasing conflicts between lodge and hotel owners and the nearby local community of the villages. Such conflicts have risen from the hunting lifestyle of the natives. Hunting activities disrupt the comfort and peace of the visitors to the lodges and hotels in the enclave area. The increasing population within the enclave would lead to a business loss for lodge and hotel owners combined with the decline in the number of animals available for viewing by the tourists. As the population in the area increases, identifying new areas for settlement would ensure sustainable settlements with peaceful human-wildlife conflict. Besides, the increased settlement in the Kasane Forest reserve has caused significant environmental issues arising from waste generation by the community and mining of construction materials from within the forest reserve.

\subsection{Assessment Criteria}

A review of the literature and several recommendations set forth by previous studies was conducted to assess all aspects of human settlement development. Factors considered included social, economic and ecological factors that would influence potential settlement areas. Therefore, the following factors were used as the evaluation factors for the sustainable and conflict-free settlement areas; availability of Tourism sites, elevation, soils, protected areas (Forest reserves and National Park, hydrology (Rivers), towns and existing settlements and roads. The description of the different indicators used in this study is indicated below (Table 1). 
Table 1. Description of indicators of development of settlements in Chobe District

\begin{tabular}{|c|c|}
\hline Indi & Description \\
\hline $\begin{array}{l}\text { Distance to } \\
\text { protected } \\
\text { areas }\end{array}$ & $\begin{array}{l}\text { Protected areas occupy the most significant part of the district's total land area. The area includes the Chobe } \\
\text { National Park (CNP), six protected forest reserves and extensions (Kazuma, Maikaelelo, Sibuyu, Chobe, } \\
\text { Kasane Forest Reserve, and the Kasane Forest Reserve Extension). The distance from these protected areas } \\
\text { was calculated for each pixel. Human settlements near protected areas have reported higher human-wildlife } \\
\text { conflicts compared to those leaving farther away. This study considered a 15km buffer zone from protected } \\
\text { areas as recommended by van der Sluis et al. (2017). }\end{array}$ \\
\hline $\begin{array}{l}\text { Distance to } \\
\text { tourism sites }\end{array}$ & $\begin{array}{l}\text { The criterion computed the distance to various tourism sites such as lodges, camping sites. Settlements } \\
\text { nearer to tourism sites face higher land-use conflicts due to hunting activities. }\end{array}$ \\
\hline $\begin{array}{l}\text { Distance to } \\
\text { the river }\end{array}$ & $\begin{array}{l}\text { Many herbivores, elephants, in particular, concentrate their browsing activities within relative proximity to } \\
\text { the Chobe River due to the availability of high-quality forage enabled by fertile alluvial soils, making areas } \\
\text { around rivers highly utilised, especially in dry seasons and harsh environments (Fox, 2016; Mosugelo, Moe, } \\
\text { Ringrose, \& Nellemann, 2002; Wiegand, Saltz, \& Ward, 2006). The criteria preferred areas away from the } \\
\text { rivers for developing settlements to avoid human-wildlife conflicts. The map was processed to contain } \\
\text { information on the distance from the rivers for each pixel. }\end{array}$ \\
\hline Soils & $\begin{array}{l}\text { Chobe District has the highest potential for rain-fed agriculture in Botswana, enhanced by relatively high } \\
\text { rainfall amounts and Vertisols in some parts of the district. The criteria defined the different soils into } \\
\text { agriculturally productive and unproductive soils. The criteria avoided productive agricultural soils for } \\
\text { human settlement. }\end{array}$ \\
\hline Elevation & $\begin{array}{l}\text { The criterion mapped the elevation of the land. Areas with low elevation negatively contribute to human } \\
\text { settlements' suitability due to high incidences of flooding during the heavy rainy period. }\end{array}$ \\
\hline $\begin{array}{l}\text { Distance to } \\
\text { existing } \\
\text { towns and } \\
\text { settlements }\end{array}$ & $\begin{array}{l}\text { The town of Kasane is the regional government seat and, together with Kazungula, are the most extensive } \\
\text { urban settlements in the district. The map pixels were processed to contain information about the distance } \\
\text { to the existing towns and settlements. Those sites nearer to existing settlements are preferred so as the new } \\
\text { settlements benefit from the existing social services like hospitals, water connection, sewerage services and } \\
\text { reduce costs for establishing new ones. The criteria considered an existing settlement in Chobe District. }\end{array}$ \\
\hline Land use & $\begin{array}{l}\text { This criterion considered land allocated for various uses according to the existing land use plan such as } \\
\text { industrial development, waste management, mining sites. Some land uses such as industries could provide } \\
\text { jobs and diversify the economy, while closer damping sites facilitate the settlement's safe and sustainable } \\
\text { waste management. }\end{array}$ \\
\hline $\begin{array}{l}\text { Distance to } \\
\text { roads }\end{array}$ & $\begin{array}{l}\text { Roads facilitate economic development; the criteria considered the existing road network of the area. Those } \\
\text { sites that are nearer to roads contribute in a positive way to the development of human settlements. } \\
\text { Information on the distance from the existing road network was processed and added to the pixels of the } \\
\text { map. }\end{array}$ \\
\hline $\begin{array}{l}\text { Distance to } \\
\text { schools }\end{array}$ & $\begin{array}{l}\text { The criterion considered the distance from the existing schools calculated and added to the map pixels. New } \\
\text { settlements near existing schools prevent further government expenditure on new ones, reducing the strain } \\
\text { on already limited education funding. The possibility of other social factors like health and recreation being } \\
\text { provided by the private sector, unlike education, makes the distance to schools a critical criterion in } \\
\text { establishing new settlements. Additionally, other social factors are available in locations with existing } \\
\text { settlements and towns. }\end{array}$ \\
\hline
\end{tabular}




\subsection{Determination of Criteria Weights for Contributing Factors}

Weights for the Factors were used to establish the relative contribution of each factor concerning the evaluation criteria set by assessing its performance in achieving the objective (Ferretti \& Pomarico, 2013). The Super Decision Tool software applied the pairwise comparison method to obtain the weights (Creative Decisions Foundation, 2019). The pairwise comparison of the model elements was divided into two levels: the comparison between clusters that are more general and strategic and the comparison between nodes that are more specific and detailed for each of the specific indicators considered. The relative importance or preference of indicators was rated on a scale of 1-9 points relative to the other. Table 2 shows the final weights and relative contribution of the indicator factors resulting from the pairwise comparison matrix.

\subsection{Data Source and Spatial Analysis}

Data for this study were obtained from different sources. Administrative boundary, rivers, roads and elevation shapefiles were acquired online from Diva GIS (DIVA-GIS, 2017), while soils and land use shapefiles were sourced from previously collected by the Botswana Department of Surveys and Mapping. Existing schools, tourism sites and settlements shapefiles were acquired from online Google earth and imported as Kmz files to ArcGis, then later converted into shapefiles with the help of conversion tools.

Figure 4 indicates a step by step process to determining suitable settlement areas. ArcGIS version 7.0 (ESRI, 2019) software was used for spatial analysis. Using the "multi-layered weighted map overlay technique" (weighted overlay), one of the spatial analysis methods within the ArcGIS spatial analyst tools, a model for identifying suitable land for the development of human settlements was built. Before the weighted overlay process, Distance to protected areas, existing settlements, tourism sites, productive soils, roads and existing schools were determined for each cell using the Euclidean distance tool.

The developed classes for all the factors except land use were then reclassified using the Reclassify tool into five classes and ranked from 1 to 5 with increasing levels of desirability. The Re-classed datasets were then used to plan the proposed location for the settlement areas, considering the factors and their weights indicating their level of influence. The weighted overlay technique combined all the factors following procedures indicated in ESRI (2010). Settlements in the protected areas and areas with water were restricted in addition to a $15 \mathrm{~km}$ buffer zone. The most desirable areas were ranked with 5 , while the least desirable areas were 1 . Suitable areas ranked five were considered highly suitable, 4 for moderately suitable, 3 for marginally suitable, 2 for currently not suitable, while areas with 1 and 0 were permanently Not suitable. 


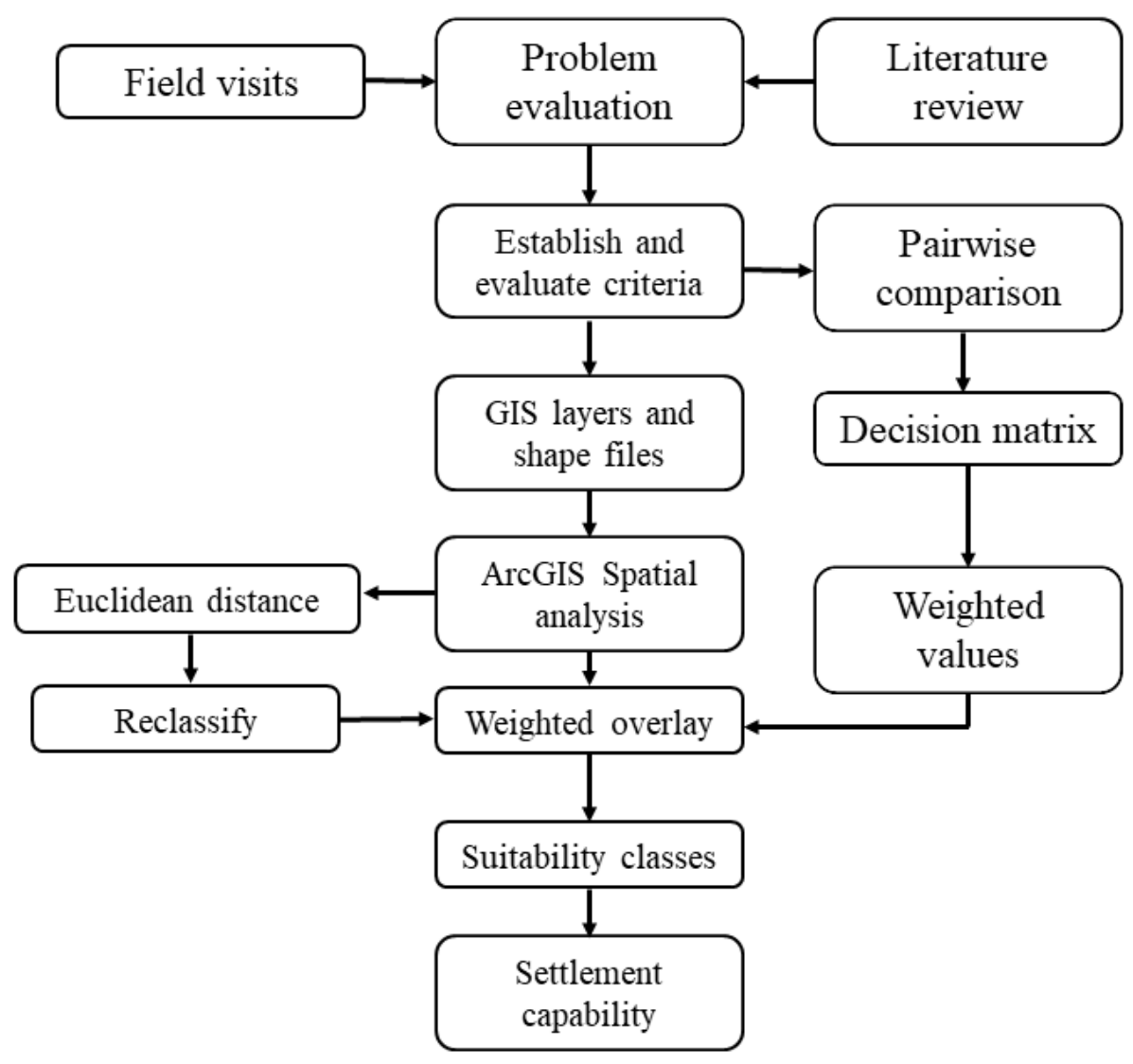

Figure 4. Research flow chart for identification of suitable settlement areas in protected areas

\section{Results and Discussions}

\subsection{Contributing Factors to Sustainable Settlements}

The management of protected areas can be complex and requires finding a balance between ecological functions, social demands and economic benefits, a situation faced by many if not all protected areas. The results of the multicriteria procedure adopted for weighting the elements considered in the model highlighted that the essential factors in determining the suitable land for development of human settlements are the "distance to protected areas" with $33 \%$ in the "Ecological factors" cluster and the "Distance to tourism sites" with $20 \%$ in the "Economic factors" cluster (Table 1). The results also indicate that the most important social factor in determining the suitability of the land for the development of human settlements is the "distance to existing schools" (13\% of importance), while the "distance to rivers" was the second most important factor (13\% of importance).

\subsubsection{Ecological Factors}

The higher contribution (33\%) by protected areas is because the most significant part of Chobe district is under protected areas (Figure 6c). A 15km buffer area was left around the protected areas as suggested by (van der Sluis et al., 2017). This study prioritised safeguarding protected areas since protected and conservation areas remain the only sustainable option for biodiversity conservation. Even though access to land within or around protected areas might be detrimental or beneficial (Joppa, Loarie, \& Pimm, 2009), it is not clear how much new settlement and developments in protected areas could alter the existing systems and habitats. These results suggest the need to consider protected areas during the planning process highly. Also, the fact that the government of Botswana is promoting local tourism within the area (J. E. Mbaiwa, 2018) has led to the increasing recognition of Chobe District as a tourism destination for tourists all year round.

Results from the reclassification analysis indicated that the influence of distance from protected areas leaves over 
$81.6 \%$ of the area permanently not suitable for settlements (Table 3 ). Only $0.5 \%$ of the area, farther away from protected areas, could be highly suitable. Additionally, other factors such as distance from productive agricultural soils, elevation, land use and distance to rivers were also analysed and found to have $12 \%$ Influence for distance from rivers, $5 \%$ for elevation, land use and distance from productive soils (Table 2). Due to rivers ' closeness, a significantly higher (52\%) proportion of the area was found permanently unsuitable. This study suggested avoiding areas closer to the river to prevent conflict for water with wildlife that tends to itinerate areas around water sources, especially during dry periods.

Table 2. Indicators and criteria weights

\begin{tabular}{lllll}
\hline Goal & Clusters & Indicators & Weight & \% weight \\
\hline & Ecological Factors & Distance to protected areas & 0.163 & 33 \\
& & Distance to Rivers & 0.061 & 12 \\
& & Elevation & 0.024 & 5 \\
Development & Soils & 0.027 & 5 \\
of sustainable & & Land use & 0.025 & 5 \\
conflict-free & \multirow{2}{*}{$\begin{array}{l}\text { Economic Factors } \\
\text { settlements }\end{array}$} & Distance to exiting towns and settlements & 0.014 & 3 \\
& & Distance to tourism sites & 0.106 & 21 \\
& & Distance to Roads & 0.013 & 3 \\
& \multirow{2}{*}{ Social factors } & Distance to schools & 0.066 & 13 \\
\hline
\end{tabular}

\subsubsection{Economic Factors and Social Factors}

Areas farther away from tourism sites such as hotels, campsites were given higher priority compared to areas closer to tourism sites (Figure $6 \mathrm{~b}$ ). Only $3.2 \%$ of the area could be highly Suitable for settlements, while the majority, $33 \%$ of the area, was unsuitable (Table 3). Restricting such areas could prevent the increasing conflicts between owners of tourism sites and their surrounding communities and ensure the peaceful stay of tourists. Higher priority was given to areas closer to schools to avoid higher government expenditure in establishing new educational institutions and roads for new settlements (Figure 5b), roads (Figure 5c) and existing settlements (Figure 5d). A significantly larger area $(60.8 \%)$ closer to existing roads was more suitable than only $17.9 \%$ for existing settlements and $19.4 \%$ for existing schools (Table 3 ). 


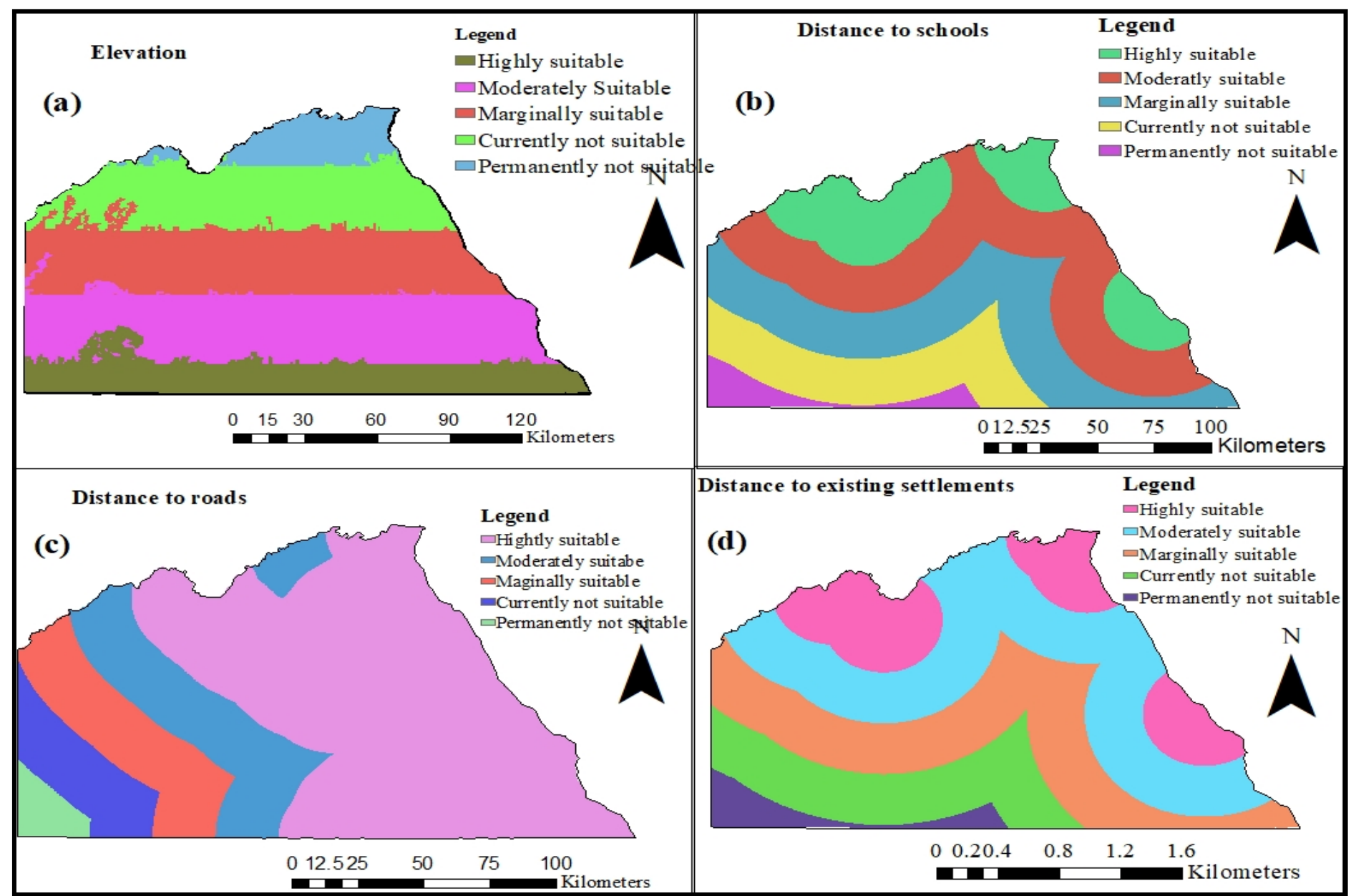

Figure 5. Standardized criteria maps for the different factors

\subsection{Suitability for Settlements}

By overlaying the layers for the different feature classes from the reclassification process, the results indicated that land restricted for protected areas and buffer zones was unsuitable for developing settlements (Figure 5 and 6). From the suitability map (Figure 7), much of the study area is Unsuitable for the development of settlements; however, significant portions of land were suitable for settlements. Additionally, a significantly smaller land area was highly suitable $(0.3 \%)$ for settlements while Moderately $(9.6 \%)$ and Marginally suitable land was significantly larger $(6.8 \%)$ (Table 3).

These results suggest that the Chobe district could better be reserved as a conservation area to prevent land-use conflicts from increasing settlements in the area. Although protected areas such as Chobe attract several activities, their effectiveness in contributing toward the protection and conservation of biodiversity is critical (Joppa et al., 2009). Hypothetically, the development of settlements around protected areas comes with developing infrastructures such as industries for employment, roads and other goods and services for human survival. Developing such infrastructure would attract larger human settlements to benefit from the urban centres that may arise. The urban area would compromise the existence of protected areas and their contribution to ecosystem conservation, local economy, livelihoods and their use as community tourism areas, Chobe District. Therefore, the development of settlement areas in the Chobe district would encourage population growth and accelerate the degradation of the natural landscape; the impact of protected areas conserving biodiversity and endangered species is thus compromised. 


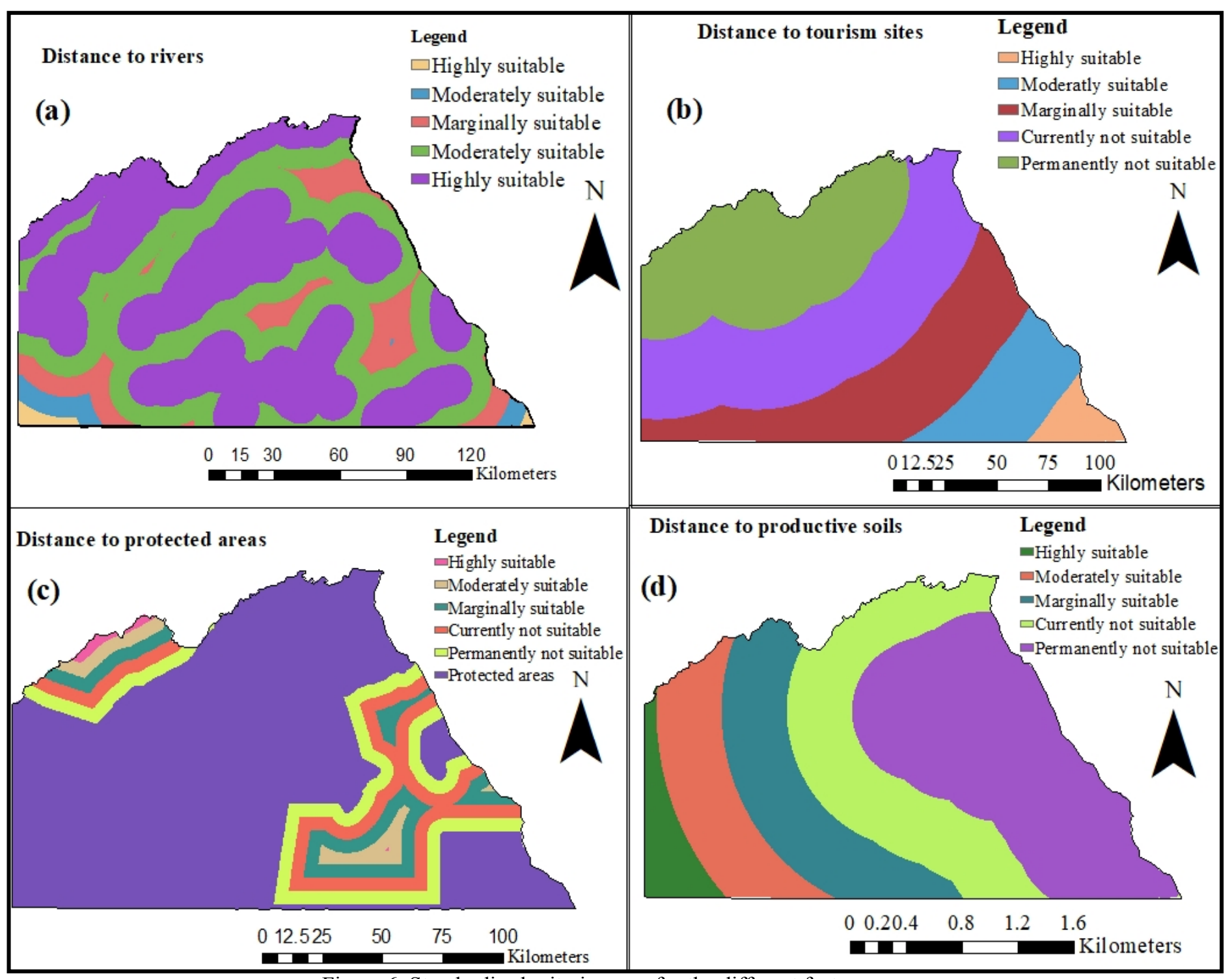

Figure 6. Standardised criteria maps for the different factors

Additionally, the Chobe District plays a critical role in achieving the sustainable development goals for the Nation through community tourism development based on the sustainable use of natural resources. The tourism activities in Chobe District have contributed to eradicating poverty through employment opportunities and economic development of the surrounding local communities (Government of Botswana, 2016). The settlements development should be such that households can meet their needs while at the same time allowing the development of economic activities that provide revenues to the national coffers. The increased revenue would foster the focus of the Chobe District development plan to secure long term sustainable utilisation and conservation of wildlife resources and management of ecosystems that support this goal.

The results indicated that most of the area classified as Highly suitable is located in the south-eastern areas of the district, while Not suitable areas occupied the majority of the areas of the district. The most significant portion of Forest reserves and National parks are in the Central and Northern sections of the district. Not suitable areas are areas occupied by Forest reserve, Chobe National Park and wildlife management areas and thus should be reserved for conservation purposes. Human settlements closer to wildlife conservation areas have reported the highest rate of land use conflict compared to areas located far from the conservation areas. 
Table 3. Area (\%) suitability of different influencing factors

\begin{tabular}{lccccc}
\hline & \multicolumn{5}{c}{ Per cent \% area } \\
\cline { 2 - 6 } Factors & S1 & S2 & S3 & N1 & N2 \\
\hline Distance Protected areas & 0.5 & 2.6 & 6.0 & 9.3 & 81.6 \\
Distance to roads & 60.8 & 16.8 & 12.2 & 7.6 & 2.6 \\
Distance to existing settlements & 17.9 & 34.0 & 26.8 & 17.0 & 4.3 \\
Distance to productive soils & 5.4 & 14.2 & 18.6 & 24.6 & 37.2 \\
Distance to schools & 19.4 & 31.9 & 26.8 & 17.5 & 4.4 \\
Distance to tourism sites & 3.2 & 10.8 & 24.5 & 32.9 & 28.7 \\
Elevation & 16.8 & 29.5 & 26.9 & 20.1 & 6.7 \\
Distance to rivers & 0.7 & 2.1 & 9.5 & 35.6 & 52.0 \\
\hline Overall Suitability & & 0.3 & 9.6 & 6.8 & 83.4 \\
\hline
\end{tabular}

S1-Highly suitable, S2-moderately suitable, S3-Margianally suitable, N1- currently not suitable, N2-Permanently not suitable

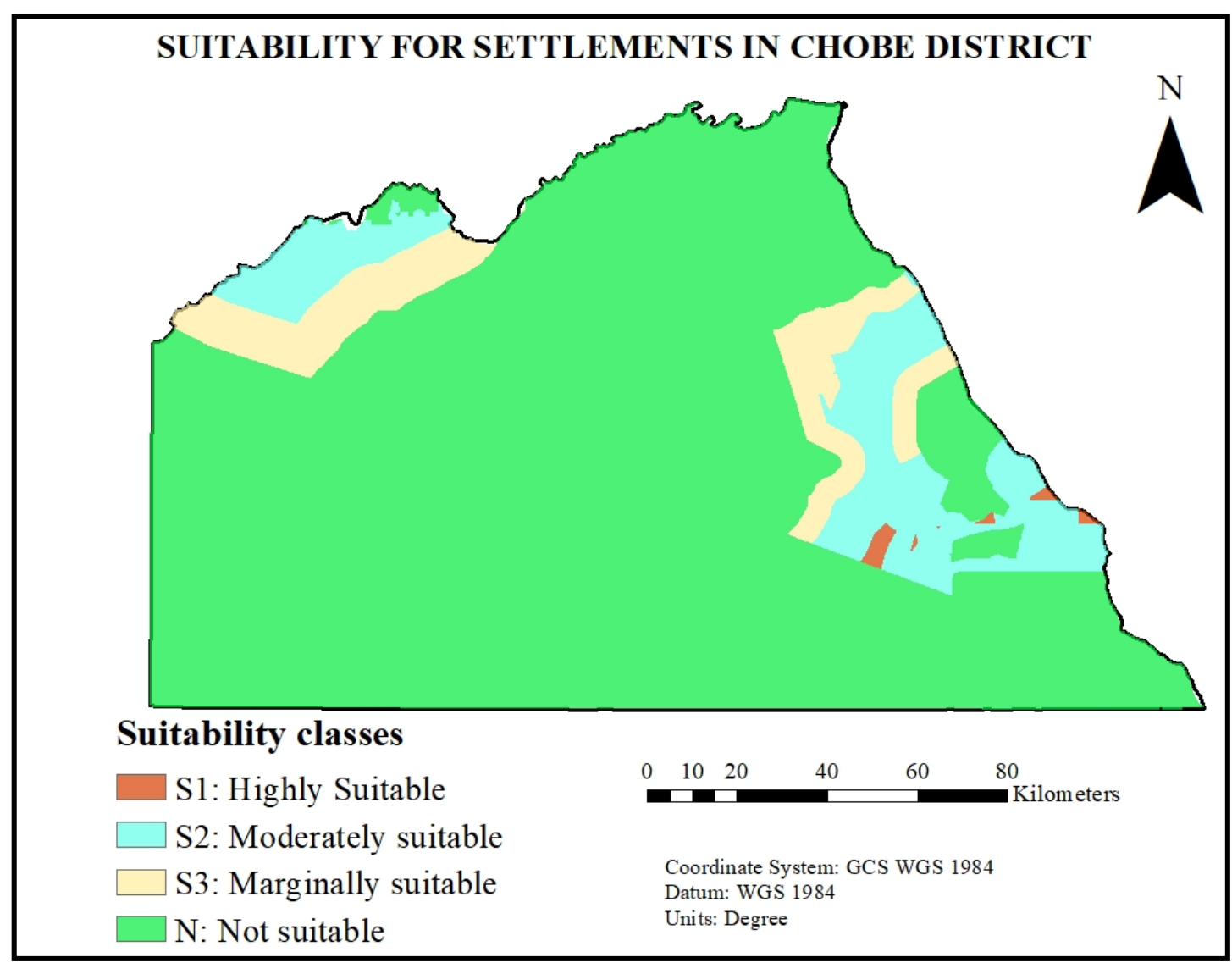

Figure 7. Chobe Land suitability map for the establishment of settlements

\section{Conclusion}

Whilst many studies on land conflicts and wildlife were conducted in Chobe District, further research is needed to model complex land resource situations in the district, considering the dynamics of human demographics, land use, and the limitations of the current land-use plan. This study explored ArcGIS spatial analyst application in land suitability evaluation and proved its effectiveness in identifying suitable settlements areas for the highly conflicted protected Chobe District. This study found that environmental factors significantly influence settlements' 
suitability than social and economic factors. These results indicate that more land for settling the increasing population should be created out of Chobe District to avoid encroachment on the conservation areas. This study demonstrated that GIS integration in the land resource planning process is a handy tool for analysing and identifying ecological, economic and social factors, thus establishing a valuable area for further research, especially for sustainable management of protected areas.

\section{Acknowledgement}

The authors acknowledge the support provided by the European Union through the Mobility of African Scholars for Transformative Engineering Training programme (MASTET) and the Department of Agricultural and Biosystems Engineering, Botswana University of Agriculture and Natural Resources. The authors also acknowledge the input from the anonymous reviewers, whose suggestions helped to improve this work.

\section{Declaration of Interests}

We declare that we have no significant competing financial, professional, or personal interests that might have influenced the performance or presentation of the work described in this manuscript

\section{References}

Adams, W. M. (2006). The Future of Sustainability: Re-thinking Environment and Development in the Twentyfirst Century. The World Conservation Union, Report of the IUCN Renowned Thinkers Meeting, 29-31 January 2006, 19. Retrieved from http://www2.ecolex.org/server2neu.php/libcat/docs/LI/MON-075076.pdf

Alexander, K. A., Ramotadima, M., \& Sanderson, C. E. (2018). The Power of Consensus: Developing a Community Voice in Land Use Planning and Tourism Development in Biodiversity Hotspots. Ecosystem Services, 30, 350-361. https://doi.org/10.1016/j.ecoser.2018.02.008

Campbell, S. (1996). Green Cities, Growing Cities, Just Cities?: Urban Planning and the Contradictions of Sustainable Development. Journal of the American Planning Association, 62(3), 296-312. https://doi.org/10.1080/01944369608975696

Creative Decisions Foundation. (2019). Super Decisions (3.2) [Windows]. Retrieved from http://www.superdecisions.com/

Digun-Aweto, O., \& Van Der Merwe, P. (2020). Coping Strategies for Human-Wildlife Conflicts: A Case Study of Adjacent Communities to Nigeria's Cross River National Park. Journal of International Wildlife Law \& Policy, 23(2), 109-126. https://doi.org/10.1080/13880292.2020.1808391

DIVA-GIS. (2017). Free Spatial Data by Country. Retrieved from http://www.diva-gis.org/gdata

ESRI, Inc. (2010). Spatial Analysis tutorial. Environmental Systems Research Institute. Retrieved from https://help.arcgis.com/en/arcgisdesktop/10.0/pdf/spatial-analyst-tutorial.pdf

ESRI, Inc. (2019). ArcGIS Desktop (Version 10.7.0) (10.7.0) [Windows]. Environmental Systems Research Institute. Retrieved from https://www.esri.com/en-us/arcgis/products/arcgis-pro/overview

Ferretti, V., \& Pomarico, S. (2013). Ecological land suitability analysis through spatial indicators: An application of the Analytic Network Process technique and Ordered Weighted Average approach. Ecological Indicators, 34, 507-519. https://doi.org/10.1016/j.ecolind.2013.06.005

Fox, J. T. (2016). Spatiotemporal Patterns and Drivers of Surface Water Quality and Landscape Change in a Semi-Arid, Southern African Savanna [Virginia Polytechnic Institute and State University]. Retrieved from https://vtechworks.lib.vt.edu/handle/10919/81462

Geldmann, J., Manica, A., Burgess, N. D., Coad, L., \& Balmford, A. (2019). A Global-Level Assessment of the Effectiveness of Protected Areas at Resisting Anthropogenic Pressures. Proceedings of the National Academy of Sciences, 116(46), 23209-23215. https://doi.org/10.1073/pnas.1908221116

Government of Botswana. (2016). Draft National Development Plan 11; April 2017-March 2023: Ministry of Finance and Development Planning, Gaborone, Botswana. Retrieved from https://library.wur.nl/ojs/index.php/Botswana_documents/article/view/16024

Graham, K., Beckerman, A. P., \& Thirgood, S. (2005). Human-Predator-Prey Conflicts: Ecological Correlates, Prey Losses and Patterns of Management. Biological Conservation, 122(2), 159-171. https://doi.org/10.1016/j.biocon.2004.06.006

Gupta, A. C. (2015). Spatial scaling of protected area influence on human demography and livelihoods in Botswana. Environmental Conservation, 42(1), 51-60. https://doi.org/10.1017/S0376892914000095 
Gwebu, T. D. (2004). Internal migration in Botswana. In: Analytical Report of 2001 Population and Housing Census, ed. Central Statistics Office, pp. 27-44. Gaborone, Botswana: Central Statistics Office.

Halseth, G., Reimer, B., Manson, D., \& Markey, S. (2009). Introduction: The Next Rural Economies. In Halseth, G., Markey, S., Bruce, D., The next rural economies: Constructing rural place in global economies. CABI. Retrieved from https://www.cabi.org/cabebooks/ebook/20103056854

Igoe, J., Brockington, D., Randall, S., \& Scholfield, K. A. (2008). Lessons to be learned about migration around protected areas. Science. Retrieved from http://www.sciencemag.org/cgi/eletters/321/5885/123?ck=nck

Izakovičová, Z., Miklós, L., \& Miklósová, V. (2018). Integrative Assessment of Land Use Conflicts. Sustainability, 10(9), 3270. https://doi.org/10.3390/su10093270

Jackson, T. P., Mosojane, S., Ferreira, S. M., \& van Aarde, R. J. (2008). Solutions for Elephant Loxodonta Africana Crop Raiding in Northern Botswana: Moving Away from Symptomatic Approaches. Oryx, 42(01). https://doi.org/10.1017/S0030605308001117

Joppa, L. N., Loarie, S. R., \& Pimm, S. L. (2009). On Population Growth Near Protected Areas. PLoS ONE, 4(1), e4279. https://doi.org/10.1371/journal.pone.0004279

Junker, J. (2008). An analysis of numerical trends in African elephant populations [Master's thesis, University of Pretoria, South Africa]. Retrieved from https://repository.up.ac.za/bitstream/handle/2263/27731/dissertation.pdf? sequence=1

Kemmonye, M. (2009). Chobe district profile, Report. Administration Center, Kasane, Botswana.

Ma, W., Jiang, G., Chen, Y., Qu, Y., Zhou, T., \& Li, W. (2020). How Feasible is Regional Integration for Reconciling Land Use Conflicts Across The Urban-Rural Interface? Evidence from Beijing-Tianjin-Hebei Metropolitan Region in China. Land Use Policy, 92, 104433. https://doi.org/10.1016/j.landusepol.2019.104433

Madden, F. (2004). Creating Coexistence between Humans and Wildlife: Global Perspectives on Local Efforts to Address Human-Wildlife Conflict. Human Dimensions of Wildlife, 9(4), 247-257. https://doi.org/10.1080/10871200490505675

Mannetti, L. (2017). Evaluating land use conflicts at the borders of Etosha National Park, Namibia: A socialecological approach. [Doctoral dessertation]. Stellenbosch University, South Africa.

Mbaiwa, J. (2011). The Effects of Tourism Development on the Sustainable Utilisation of Natural Resources in the Okavango Delta, Botswana. Current Issues in Tourism, 14(3), 251-273. https://doi.org/10.1080/13683500.2011.555525

Mbaiwa, J. E. (2018). Effects of the Safari Hunting Tourism Ban on Rural Livelihoods and Wildlife Conservation in Northern Botswana. South African Geographical Journal, 100(1), 41-61. https://doi.org/10.1080/03736245.2017.1299639

Mbaiwa, J. E., \& Stronza, A. L. (2010). The Effects of Tourism Development on Rural Livelihoods in the Okavango Delta, Botswana. Journal of Sustainable Tourism, 18(5), 635-656. https://doi.org/10.1080/09669581003653500

Mosugelo, D. K., Moe, S. R., Ringrose, S., \& Nellemann, C. (2002). Vegetation Changes During a 36-Year Period in Northern Chobe National Park, Botswana. African Journal of Ecology, 40(3), 232-240. https://doi.org/10.1046/j.1365-2028.2002.00361.x

Moswete, N. N., Thapa, B., \& Child, B. (2012). Attitudes and Opinions of Local and National Public Sector Stakeholders Towards Kgalagadi Transfrontier Park, Botswana. International Journal of Sustainable Development \& World Ecology, 19(1), 67-80. https://doi.org/10.1080/13504509.2011.592551

Murti, A. (2019). Environmentally sensitive areas still battle human encroachment in more than 150 countries. The Swaddle. Retrieved from https://theswaddle.com/encroachment-in-environmentally-sensitive-areas/

Nabielek, K., Kronberger-Nabielek, P., \& Hamers, D. (2013). The Rural-Urban Fringe in the Netherlands: Recent Developments and Future Challenges. SPOOL, 101-120 Pages. https://doi.org/10.7480/SPOOL.2013.1.624

Nijhawan, S. (2008). Understanding human-large carnivore conflict in Chobe, Botswana. [Master's Thesis, Duke University, Durham, North Carolina, USA]. Retrieved from https://edepot.wur.nl/419817

Nyhus, P. J. (2016). Human-Wildlife Conflict and Coexistence. Annual Review of Environment and Resources, 41(1), 143-171. https://doi.org/10.1146/annurev-environ-110615-085634 
Peterson, M. N., Birckhead, J. L., Leong, K., Peterson, M. J., \& Peterson, T. R. (2010). Rearticulating the Myth of Human-Wildlife Conflict. Conservation Letters, 3(2), 74-82. https://doi.org/10.1111/j.1755263X.2010.00099.X

Pinnock, D. (2011). Okavango wildlife threatened. Mail and Guardian Online. Retrieved from https://elephantswithoutborders.org/downloadspapers/Okavango_wildlife_threatened.pdf

Rodríguez, R. A. P. (2017). A stepwise approach to understanding and effectively mitigating human-wildlife interactions [Doctoral Dissertation, University of Oxford Kellogg College, Oxford, England]. Retrieved from https://ora.ox.ac.uk/objects/uuid:1b3f1379-a04e-45fa-ba85-

e24b2d3dee00/download_file?file_format=pdf\&safe_filename=RocioPozo_DPhil_Thesis.pdf\&type_of_wo $\mathrm{rk}=$ Thesis

Romañach, S. S., Lindsey, P. A., \& Woodroffe, R. (2011). Attitudes Toward Predators and Options for Their Conservation in the Ewaso Ecosystem. Smithsonian Contributions to Zoology, 632, 85-93. https://doi.org/10.5479/si.00810282.632.85

Soulsbury, C. D., \& White, P. C. L. (2015). Human-Wildlife Interactions In Urban Areas: A Review of Conflicts, Benefits and Opportunities. Wildlife Research, 42(7), 541-553. https://doi.org/10.1071/WR14229

Stokke, S., \& Toit, J. T. du. (2014). The Chobe Elephants: One Species, Two Niches. In Elephants and Savanna Woodland Ecosystems (pp. 104-117). John Wiley \& Sons, Ltd. https://doi.org/10.1002/9781118858615.ch7

Stone, M. T. (2013). Protected areas, tourism and rural community livelihoods in Botswana [Doctoral Dissertation, Tempe, Arizona State University, Arizona, USA]. Retrieved from https://repository.asu.edu/attachments/114539/content/Stone_asu_0010E_13150.pdf

United Nations Environment Programme World Conservation Monitoring Centre, International Union for Conservation of Nature and National Geographic Society. (2019). Protected planet life report 2019. UNEPWCMC, IUCN and NGS, Cambridge UK, Gland, Switzerland; and Washington, D.C., USA. Retrieved from https://livereport.protectedplanet.net/

van der Sluis, T., Cassidy, L., Brooks, C., Wolski, P., VanderPost, C., Wit, P., ... Veenendaal, E. (2017). Chobe district integrated land use plan (p. 186). Wageningen Environmental Research. https://doi.org/10.18174/419817

von der Dunk, A., Grêt-Regamey, A., Dalang, T., \& Hersperger, A. M. (2011). Defining a Typology of Peri-Urban Land-Use Conflicts - A Case Study from Switzerland. Landscape and Urban Planning, 101(2), 149-156. https://doi.org/10.1016/j.landurbplan.2011.02.007

Watson, F. G. R., Becker, M. S., Milanzi, J., \& Nyirenda, M. (2015). Human Encroachment into Protected Area Networks in Zambia: Implications for Large Carnivore Conservation. Regional Environmental Change, 15(2), 415-429. https://doi.org/10.1007/s10113-014-0629-5

West, P., Igoe, J., \& Brockington, D. (2006). Parks and Peoples: The Social Impact of Protected Areas. Annual Review of Anthropology, 35(1), 251-277. https://doi.org/10.1146/annurev.anthro.35.081705.123308

Wiegand, K., Saltz, D., \& Ward, D. (2006). A Patch-Dynamics Approach to Savanna Dynamics and Woody Plant Encroachment - Insights From an Arid Savanna. Perspectives in Plant Ecology, Evolution and Systematics, 7(4), 229-242. https://doi.org/10.1016/j.ppees.2005.10.001

\section{Copyrights}

Copyright for this article is retained by the author(s), with first publication rights granted to the journal.

This is an open-access article distributed under the terms and conditions of the Creative Commons Attribution license (http://creativecommons.org/licenses/by/4.0/). 